\title{
Probiotic P. acidilactici application in shrimp Litopenaeus stylirostris culture subject to vibriosis in New Caledonia
}

\author{
Mathieu Castex ${ }^{\mathrm{a}, \mathrm{c}}$, *, Liet Chim ${ }^{\mathrm{a}}$, Dominique Pham ${ }^{\mathrm{a}}$, Pierrette Lemaire ${ }^{\mathrm{a}}$, Nelly Wabete ${ }^{\mathrm{a}}$, Jean- \\ Louis Nicolas ${ }^{b}$, Philippe Schmidely ${ }^{c}$ and Catherine Mariojouls ${ }^{c}$

\footnotetext{
a IFREMER, Département Aquaculture en Nouvelle-Calédonie, BP 2059, 98846 Nouméa cedex, New Caledonia

b IFREMER, Laboratoire de physiologie des invertébrés, DRVIA, centre de Brest, 29280 Plouzané, France
} \\ ${ }^{c}$ AgroParisTech, 16 rue Claude Bernard, 75231 Paris, Cedex 5, France
}

*: Corresponding author : M. Castex, email address : Mathieu.Castex@ifremer.fr

\begin{abstract}
:
We studied the effects of a lactic acid bacterium, Pediococcus acidilactici (strain MA 18/5M, CNCM), as a dietary probiotic on growth performance and some nutritional and microbiological aspects of the shrimp Litopenaeus stylirostris. Experimental shrimp culture was carried out over 10 weeks, using floating cages of $14 \mathrm{~m} 2$ each set in earthen ponds, in a New Caledonia farm affected by "Summer syndrome", a septicaemic vibriosis caused by Vibrio nigripulchritudo. The experiment design testing probiotic-coated pellets against control was replicated in two earthen ponds. High mortalities, characteristic of Summer syndrome, were observed during the first 2 weeks of the trial. The probiotic improved production in the treated cages from both ponds with increases in the survival rate $(7 \%$ and $15 \%$ respectively) and final biomass ( $8 \%$ and $12 \%$ respectively). No differences were recorded among treatments on growth performances, but significant lower food conversion ratios were obtained with probiotic treatment. After 5 weeks of rearing, the Hepatosomatic Index and the adjusted dry weight of the digestive gland were significantly increased by $10 \%$ and by $9 \%$ respectively in shrimps treated with probiotic. In the meantime, the specific activities of greek small letter alpha amylase and trypsin in the digestive gland showed a significant effect of the probiotic treatment with respective increases by $35 \%$ and $55 \%$. The rise in total trypsin activity following morning feeding was also enhanced by the probiotic treatment $(P<0.001)$.

The highest concentration of probiotic (between 104-105 CFU g- 1 of fresh gut) in the shrimp gut was obtained $2 \mathrm{~h}$ after feeding. The concentration remained high for $4 \mathrm{~h}$ after feeding before decreasing until the next meal. Total bacterial counts on Marine agar and TCBS in the gut were significantly lowered by the probiotic treatment over the 10 weeks of the experiment. Additionally, during the first 2 weeks, prevalence and load of $\mathrm{V}$. nigripulchritudo strains in haemolymph was lower in animals fed with the probiotic diet.
\end{abstract}

This study demonstrated, under pond conditions, that feeding shrimp with live terrestrial lactic acid bacteria can be an effective treatment for improving shrimp culture affected by vibriosis.

Keywords: Probiotic; Pediococcus acidilactici; Litopenaeus stylirostris; Floating cages; Vibriosis 


\section{Introduction}

Vibriosis is currently one of the main diseases affecting shrimp culture and outbreaks lead to dramatic crop failures in the major shrimp-producing countries (Lightner, 1988; Lin, 1995). In New Caledonia, shrimp farming faces two diseases of bacterial origin: "Syndrome 93" (Le Groumellec et al., 1996) and "Summer syndrome" (Goarant et al., 2006). In recent years, the biological control of diseases by environmental friendly methods such as probiotics has become an important subject of investigation in aquaculture research. Several reviews (Garriques and Arevalo, 1995; Gatesoupe, 1999; Vershuere et al., 2000; Gomez-Gil et al., 2000; Irianto and Austin, 2002; Vine et al., 2006) detail the various developments made in the use of probiotics in aquatic cultured species, including shrimp. The use of probiotic bacteria is now commonly accepted in shrimp farming. The main probiotic bacteria documented in shrimp grow-out are Bacillus spp. strains (Moriarty, 1998; Ziaei-Nejad et al., 2006) such as Bacillus subtilis (Vaseeharan and Ramasamy, 2003; Moriarty, 1999) or Gram-negative bacteria strains (Garriques and Arevalo, 1995; Alavandi et al., 2004; Vijayan et al., 2006). However, since current regulations make it mandatory to obtain authorisation for zootechnical application of living micro-organisms, the use of already identified bacteria will tend to be increasingly extended to aquaculture (Gatesoupe, 2002b). Because lactic acid bacteria (LAB) are the most commonly applied probiotics in terrestrial animal nutrition, their use as probiotics has been proposed for aquatic species (Gatesoupe, 1991, 1994, 2002a, Ringø and Gatesoupe, 1998). LABs potentially have several probiotic properties: they may stimulate the growth of preferred micro-organisms, outcompete harmful bacteria, and reinforce the organism's natural defence mechanisms (Vandenbergh, 1993, Villamil et al., 2002). Studies showing such effects on aquatic species have generally assessed strains of Lactobacillus acidophilus, L. sporogenes, L. rhamnosus., L. plantarum, Carnobacterium divergens sp., Lactococcus lactis and Pediococcus acidilactici (Strøm and Ringø, 1993; Gatesoupe, 1991, 2002a; Gatesoupe et al., 1989; Gildberg et al., 1995, 1997; Nikoskelainen et al., 2001; Planas et al., 2004). However, only a few reports about their use on shrimp have been documented (Uma et al., 1999; Venkat et al., 2004). The available information on the probiotic Pediococcus acidilactici MA 18/5 M (Bactocell囚) provides convincing safety back-up ("Generally Recognized as Safe" (GRAS) and "Qualified Presumption of Safety" (QPS) status) and evidence of its effectiveness since its use has been authorized by the European committee for several terrestrial species (E1712 for broiler chicken and E1712 for fattening pig). In addition, first evaluations of its effects on the species Litopenaeus stylirostris reared in New Caledonia have shown promising results as regards the growth and survival of shrimps affected by Syndrome 93 (Chim et al., 2005; Castex et al., 2006).

The present study aimed to assess the probiotic strain Pediococcus acidilactici MA 18/5 M on a pilot scale, using floating cages as an original tool for experimental purposes. Our investigation focused on zootechnical results, nutritional status and gut microflora of the blue shrimp, L. stylirostris, reared in 20 floating cages set up in two earthen ponds of a farm currently affected by Summer syndrome.

\section{Materials and Methods}

\subsection{Farm site, study period and temperatures}

The study took place in two earthen ponds of 10 ha each (pond $A$ and pond $B$ ) of a semi-intensive farm located in Bourake, New Caledonia (21 ${ }^{\circ} 55^{\prime}$ South; $165^{\circ} 57^{\prime}$ East) that has been affected since 1997 by Summer syndrome. The experiment was conducted over 10 weeks in 2006, from April to June, the usual period for outbreaks of this disease.

The water temperature during the trial (Figure 1) was within the thermal preferendum of L. stylirostris (Wabete, 2005) except for the two first weeks when the temperature rose above the upper limit of this preferendum.

\subsection{Shrimp rearing}

\subsubsection{Rearing in ponds}

The animals used in this experiment were first pregrown in the two ponds: on February 21, ponds $A$ and $B$ of the farm were stocked at a density of respectively 17 and 18 post larvae (PL). $\mathrm{m}^{-2}$ with 
animals that originated from the same hatchery batch. The animals were reared according to standard semi-intensive farming practices in New Caledonia until they reached the desired size.

Shrimps were fed twice a day with a commercial formulated feed. The feeding rate was adjusted by the technical staff of the farm according to the weekly estimated body weight, survival rate and amount of remaining feed in the feeding tray 2 hours after feeding.

\subsubsection{Seeding and rearing in floating cages}

Twenty floating cages of $14 \mathrm{~m}^{2}$ of net surface or $4 \mathrm{~m}^{3}$ each were used as described in a previous study (Chim et al., 2007). Thirty-six and thirty-seven days after seeding the ponds, the cages were stocked with pregrown shrimps taken from the same pond they were reared in. Each cage was stocked with 400 animals for a final density of 29 animals. $\mathrm{m}^{-2}$. This density has been determined based on the sampling scheme in order to not affect the final survival rates (Bouyer, 1997). The density in cage was higher than the one in the respective ponds, but it was of little importance since the aim of this study was not to compare the both rearing systems (pond vs cage). The average initial bodyweight of shrimps was $3.4 \mathrm{~g} \pm 0.57$ (SD) and $2.7 \mathrm{~g} \pm 0.68$ (SD) in pond $A$ and pond $B$ respectively.

Shrimps were fed only in the feeding tray, twice a day, at $8.00 \mathrm{am}$ and $3.00 \mathrm{pm}$. The feeding rate was adjusted every day for each cage according to the feed remaining 2 hours after the meals.

\subsection{Experimental design}

The experiment was conducted as a randomized design, based on previous study (Chim et al., 2007), with two treatments: standard diet vs. diet supplemented with probiotic. Each group consists of 5 replicates: 5 control cages (C-Cages) and 5 cages receiving probiotic diet (P-Cages). This protocol was duplicated in the two earthen ponds giving a total of 20 floating cages. Table 1 summarizes the experimental protocol. Experimental units considered and tested effects are detailed in the following statistical analysis section.

Feeding with probiotic started on 5 April (day 0), one week after stocking the cages with the shrimps. Previously, all the shrimps had received the same standard commercial diet.

Shrimps were sampled weekly in one C-Cage and one P-Cage, alternatively in pond A and B, and each cage was sampled only once in the course of the trial. Each sample consisted of 2 groups of 15 shrimps: the first group was sampled one hour before the meal $(7 \mathrm{am})$ and the second sampled two hours after the meal $(10 \mathrm{am})$. The animals were captured with a cast net spread along the surface of the cage and dropped down. The samples were immediately placed in sterile containers of 5 shrimps each, packed on ice in a cooler and brought to the laboratory within 30 min. On the 65th day of the trial (9th week) we carried out a follow-up by sampling shrimps every two hours (from 7 am to $9 \mathrm{pm}$ ) in one cage for each treatment.

As described below, the animals sampled in the cages were used for several analyses. In addition, 30 shrimps were sampled weekly in each pond, outside the cages, only for microbiological analysis in the haemolyph.

\subsection{Shrimp feed and probiotic}

Shrimps in the cages were fed with the same commercial diet used in the ponds, purchased from the company Moulins de Saint Vincent (MSV), New Caledonia.

The commercial probiotic preparation tested was Bactocell ${ }^{\circledR}$ PA 10 (Lallemand Animal Nutrition S.A., Blagnac, France) formulated with live Pediococcus acidilactici MA 18/5 M (Institut Pasteur, Paris, France). The concentration used in this experiment had been previously determined as effective (Castex et al., 2006). For the treated group, $1 \mathrm{~g} \cdot \mathrm{kg}^{-1}$ of the probiotic (powder form) was top-coated on the pellets using $3 \%$ of fish oil as a carrier, giving a final concentration of $9.7 \pm 1.110^{6} \mathrm{CFU}$ of $P$. acidilactici per gram of diet. The probiotic concentration in the feed was systematically checked after processing by counting $P$. acidilactici strains on MRS plates using serial dilution. The control diet was also top-coated with $3 \%$ fish oil and, prior to use, checked for possible contamination by the probiotic strain. 
Feeds were then stored in 5 -litre boxes at $20^{\circ} \mathrm{C}$ until use. The storage period never exceeded 15 days, in order to guarantee the same amount of probiotic in the feed throughout the experiment, since we determined that the $P$. acidilactici concentration in shrimp feed started to decrease significantly after this period (unpublished data).

\subsection{Zootechnical parameters}

The final survival rates were calculated for each cage by counting the number of remaining shrimps and comparing it with the initial stock, excluding the 30 sampled animals per cage. It is statistically agreed that sampling less than $10 \%$ of the initial population does not affect the survival rate (Bouyer, 1997).

The individual body weights were recorded for $10 \%$ of the population at stocking and for all the remaining shrimps at the end of the experiment. Weekly sampled shrimps were also individually weighed. At the end, final body weight, final biomass and feed conversion ratio (FCR) were determined.

\subsection{Moulting stage}

The moulting stage (Drach and Tchernifovtzeff, 1967) of sampled animals was recorded. Only shrimps in the intermoult stage (C-D0) were considered for nutritional status and microbiological analysis.

\subsection{Nutritional status}

\subsubsection{Hepatosomatic index and hepatopancreas adjusted dry weight}

The hepatopancreas is recognized as the main storage organ in shrimp (Luvizotto-Santos et al., 2003), and is therefore commonly accepted as a good indicator of nutritional status. Sampled shrimps were dissected and the hepatopancreas was carefully removed and weighed (wet weight). Hepatosomatic index ( $\mathrm{HSI}$ ) was calculated individually as the ratio between wet hepatopancreas weight and total wet body weight. Samples were then frozen at $-80^{\circ} \mathrm{C}$ prior to the freeze-dry step (Alpha 1-2/LD apparatus, Fisher Bioblock Scientific, 48 hours at $-55^{\circ} \mathrm{C}$ ) and then weighed to obtain dry weight. The hepatopancreas dry weight, adjusted for its wet weight, was compared between treatments, and used as a complementary index to evaluate the nutritional status of the shrimps. The linear relationship between fresh weight and dry weight of the digestive gland $\left(R^{2}=90.68\right.$, in this case) allows hepatopancreas dry weight to be compared with the fresh weight as covariable, using a covariance analysis (Sokal and Rohlf, 1995)..

\subsubsection{Protein and enzyme assays}

During the one-day follow-up in the cages, the sampled hepatopancreas were frozen at once in liquid nitrogen and stored at $-80^{\circ} \mathrm{C}$ until enzyme assays were conducted. Only shrimps in intermoult (stage C-D0) were used, since digestive enzyme activity changes with the moulting stage (Fernández et al., 1997). The hepatopancreas, previously weighed, were homogenized individually in Tris buffer $10 \mathrm{mM}$, $\mathrm{pH} 7.4$ with an ultraturrax and centrifuged $10 \mathrm{~min}$ at $4000 \mathrm{rpm}$ at $4^{\circ} \mathrm{C}$. Proteins were estimated according to Lowry et al. (1951) with BSA standard. Trypsin was assayed by its amidase activity using benzoyl-Arginine-p-nitroanalide (BAPNA) as substrate following the method of Erlanger et al. (1961) and García-Carreño et al. (1994). Assays were initiated by the addition of sample supernatant, and the release of $p$-nitroanalide was measured at $410 \mathrm{~nm}$ over $15 \mathrm{~min}$. A positive control of $3 \mathrm{mg} \mathrm{ml}^{-1}$ trypsin (SIGMA) was used. BAPNA units were evaluated in accordance with Haard et al. (1996). One activity unit was expressed as $1 \mu \mathrm{mol}$ of $\mathrm{p}$-nitroanilide released. $\mathrm{min}^{-1}$. The a Amylase activity was assayed by Bernfeld's method (1955), using 1\% soluble starch (SIGMA) as substrate in phosphate buffer $20 \mathrm{mM}$, $\mathrm{pH} \mathrm{7,} \mathrm{and} \mathrm{reacting} \mathrm{it} \mathrm{with} \mathrm{3,5-dinitrosalicylic} \mathrm{acid.} \mathrm{One} \mathrm{unit} \mathrm{of} \mathrm{enzymatic} \mathrm{activity} \mathrm{was} \mathrm{defined} \mathrm{as} 1 \mathrm{mg}$ of 
maltose liberated in $15 \mathrm{~min}$ at $37^{\circ} \mathrm{C}$. Units of enzyme activities were expressed both as total $(\mathrm{U} / \mathrm{mg}$ of organ) and specific (U/mg of protein) activities.

\subsection{Microbiological analysis}

\subsubsection{Haemolymph}

Haemolymph was collected, after rinsing the shrimps with sterile seawater, from the ventral-sinus cavity (venous blood) using a $1 \mathrm{ml}$ sterile needle and syringe. Samples were then plated on Marine

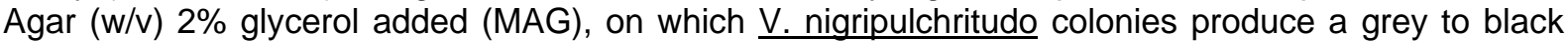
pigment (Baumann and Schubert, 1984). Plates were incubated for $72 \mathrm{~h}$ to $96 \mathrm{~h}$ at $29^{\circ} \mathrm{C}$. The number of putative $\underline{\mathrm{V}}$. nigripulchritudo colonies was counted and recorded for each animal. Then the prevalence was determined as the percentage of animals presenting at least one $\underline{V}$. nigripulchritudo colony, and the load as the number of colonies per infected animal. Prevalence and load were determined weekly for shrimps sampled in P-cages and C-cages, and in the ponds.

\subsubsection{Gut microbiota}

Shrimps were dissected using sterilized surgical scissors to remove mid- and hindgut (intestine) (Dall, 1967). To avoid possible external contamination while removing organs, the surface of each shrimp was previously cleaned using $70 \%$ ethanol (Sakata, 1989). The hindgut of 5 shrimps were pooled, placed in a sterile tube containing $1 \mathrm{ml}$ of sterile artificial sea-water and weighed before homogenization.

Bacteriological determination was made using serial dilution in sterile saline solution followed by plating triplicates on Marine agar (MA), Thiosulfate citrate bile salt agar (TCBS) and De Man, Rogosa and Sharpe agar (MRS), in order to determine respectively total cultivable heterotrophic marine bacteria, Vibrio sp. and Pediococcus acidilactici. After incubation (24h and $48 \mathrm{~h}$ at $29^{\circ} \mathrm{C}$ for MA and TCBS plates, and $48 \mathrm{~h}$ to $37^{\circ} \mathrm{C}$ for MRS plates) colonies were counted and recorded. All the results are presented as colony-forming units per gram of fresh digestive tract $\left(\mathrm{CFU} \cdot \mathrm{g}^{-1}\right)$.

\subsection{Statistical analysis}

The data were statistically analysed by the statistical package Stat View (SAS Inc., Cary, NC, USA). Zootechnical results were analysed as follows: each cage was considered as the experimental unit and pond and treatment effects were considered as fixed effects. The normality and variance's homogeneity of all data were systematically checked before applying one-way analysis of variance or two-way analysis of variance for the FCR and the daily growth rates (pond, treatment and their interaction). The interaction pond*treatment was systematically checked and was never significant. Survival rates were assessed using the Chi-square test to determine significant differences between treatments and by analysis of variance after arcsine transformation of percentages survival.

For other analysis (microbiological and nutritional), shrimps or pool of shrimps were considered as experimental unit. ANOVA were used to compare treatment effect. The bacterial counts were log transformed before running ANOVA. When ANOVA was not applicable, comparisons were made using the Kruskal-Wallis test.

Pairwise comparisons were also achieved using Fisher's Protected Least Significant Difference (PLSD). Statistically significant differences among experimental groups were reported at $P<0.05$. 


\section{Results}

\subsection{Zootechnical results.}

The average zootechnical results for shrimps reared in the ponds were similar to the farm's previous crops. According to the farmer's results, the estimated survival rates were $31 \%$ for both ponds.

Table 2 summarizes the zootechnical results of shrimps reared in cages for both ponds. The mean survival rates were respectively $31.1 \pm 3.4 \%$ and $37.8 \pm 4.2 \%$ for $\mathrm{C}$-cages in pond $\mathrm{A}$ and in pond $\mathrm{B}$ $(P<0.001)$. The values obtained for the growth rate and FCR in cages fit into the results range of farms in New Caledonia (GFA, 2006). Mortality records (number of dead shrimp discovered daily) according to rearing time were almost similar for shrimps reared in cages and directly in ponds with a rise one week after the beginning of the trial (Fig. 6C).

Probiotic treatment significantly improves the survival rate $(P<0.001)$ and the food conversion ratio $(P<0.05)$ (Table 2). In P-cages, survival was higher by $7 \%$ and $15 \%$ and $F C R$ lower by $8 \%$ and $9 \%$ compared to $\mathrm{C}$-cages in pond $\mathrm{A}$ and pond $\mathrm{B}$ respectively.

No significant effect of the probiotic treatment on GR $(P>0.05)$, final weight of the animals $(P>0.05)$ or final biomass $(P=0.09)$ was shown in either pond.

\subsection{Influence of probiotic on nutritional status}

Figure 2 shows the evolution of the HSI before the morning meal for both treatments $(P>0.05)$ and of the body weight of the shrimps irrespective of the treatment. From week 5 to the end of the trial, HSI was significantly higher for shrimp receiving the probiotic treatment $(P<0.05)$. These differences were observed when the mean value of body weight was higher than $10 \mathrm{~g}$.

In addition, compared to C-cages, the adjusted dry weight of the digestive gland was significantly higher $(\mathrm{P}<0.05)$ for animals from $\mathrm{P}$-Cages from week 8 to the end of the trial (Table 3.).

Figure 3 presents total and specific activities for trypsin (Fig 3A\&B) and $\alpha$ amylase (Fig 3C\&D) in the digestive gland. In control shrimps, total and specific activities of both enzymes showed the same trend over the day: at 10.00am (two hours after the first meal) significant rises in trypsin activities (total $\mathrm{P}<0.001$; specific $\mathrm{P}<0.05$ ) and amylase activities (total $\mathrm{P}<0.001$; specific $\mathrm{P}<0.05$ ) were recorded. At $2.00 \mathrm{pm}$ the activities returned to the initial levels, except for total amylase activity which stayed high until 9.00pm (Fig. 3C). No significant evolution of either enzyme activity was recorded after the second meal (3.00pm).

In shrimps fed with probiotic, the activities of both enzymes varied the same way as for control animals, with an increase in enzymes activities following the first meal. However, differences were observed for treated animals compared to control: (i) at 7.00am (before the first meal), total and specific activities of trypsin and $\alpha$ amylase were significantly higher, (ii) at $10.00 \mathrm{am}$, the rise of total trypsin activity was also found to be significantly higher (Fig. 3A), (iii) the activity levels of both enzymes returned down to initial values at $12.00 \mathrm{pm}$ instead of $2.00 \mathrm{pm}$ as recorded for control animals, (iv) the specific trypsin activity recorded from $2.00 \mathrm{pm}$ to $9.00 \mathrm{pm}$ remained at levels significantly higher $(\mathrm{P}<0.05)$ in probiotic group (Fig. 3B).

\subsection{Microbial flora in digestive tract of $L$. stylirostris}

\subsubsection{Probiotic recovered}

P. acidilactici was never detected in animals from C-Cages. In P-Cages, there were significant differences for the concentration of probiotic recorded in the intestine before and after the meal (Table 4). Before morning feeding, P. acidilactici was usually not detected, but it was found successively on three occasions (weeks 5, 7 and 8) with concentrations close to $10^{2}$ CFU. ${ }^{-1}$. Two hours after feeding, the concentrations of $\mathrm{P}$. acidilactici reached mean value of $1.3 \times 10^{4} \mathrm{CFU} \cdot \mathrm{g}^{-1}$ throughout the experiment (Table 4). Subsequently the probiotic concentration in the shrimp gut decreased to reach values around $2.3 \times 10^{3}$ six hours post feeding (Table 5). 


\subsubsection{Bacterial numeration}

For control groups, the results of the weekly sampling did not show any significant effect of the meal on total heterotrophic bacteria and Vibrios counts in the digestive tract (Table 6). Total bacterial counts slightly increased during the first weeks of the trial to reach high and stable levels thereafter (Fig.4), while Vibrios, according to TCBS counts, increased dramatically at week $5(P<0.001)$ to remain high until the end.

The results of sampling over one day are shown in Figure 5: heterotrophic bacteria and Vibrios counts increased exponentially from $7 \mathrm{am}$ to $7 \mathrm{pm}$ and decrease afterwards. These increases were statistically significant, with values rising from $2.8 \times 10^{7} \mathrm{CFU} \cdot \mathrm{g}^{-1}$ to $5.8 \times 10^{8} \mathrm{CFU} \cdot \mathrm{g}^{-1}$ for the total heterotrophic bacteria, and from $1.5 \times 10^{6}$ to $1.8 \times 10^{7} \mathrm{CFU} \cdot \mathrm{g}^{-1}$ for Vibrios. On the same day, recorded temperatures increased from $21.5^{\circ} \mathrm{C}$ at $7 \mathrm{am}$ to $25^{\circ} \mathrm{C}$ at $4 \mathrm{pm}$.

For the probiotic group, total heterotrophic bacteria and Vibrios counts in the digestive tract followed the same trends as the control group (Fig.4 \& 5). However, the following differences were recorded: (i) weekly sampling showed that two hours post feeding, bacterial counts were significantly lowered by the probiotic treatment on both MA $(P<0.05)$ and TCBS $(P<0.001)$ media (Fig.4) even if those variations are not uniform over the weeks, (ii) the follow-up over a day showed that the same decrease occurred after each meal supplemented with the probiotic and that this effect lasted longer after the second meal (Fig. 5).

Counts on MAG did not allow the relevant number of $\mathrm{V}$. nigripulchritudo colonies in the gut to be detected at any time at the dilutions achieved (data not shown). Only very few colonies were detected on one plate of the first dilution $\left(10^{-1}\right)$ at week one and week four, without noticing any differences between treatments.

\subsection{V. nigripulchritudo counts in the haemolymph}

Haemocultures on MAG for V. nigripulchritudo prevalence and load, in shrimps raised in ponds, are shown in Figure 6. Prevalence levels at the beginning of the trial were high and decreased throughout the trial to reach nul value at week 10 (Fig. 6A). This decrease was found to be highly correlated with water temperature (Table 7). V.nigripulchritudo load rose dramatically on week 2 and then decreased to less than $20 \mathrm{CFU}$ per infected shrimp during the following weeks (Fig. 6C). The same trends in prevalence and load were observed for shrimps reared in C-cages (Fig. 6B\&D). Compared to Ccages, P-Cages had lower prevalence at weeks 2, 3, 4, 8 and 10 and lower load at weeks 2 and 5 (Fig. 6 B\&D). For probiotic treated animals, the maximum prevalence values, from week 2 of the trial to the end, did not exceed $53 \%$. Moreover, the prevalence pattern for shrimp fed probiotic was not correlated with the fall in temperature as observed for control (Fig. 6B and Table 7). Finally the V. nigripulchritudo load in P-cage did not increase in week 2 of the trial, as was observed for animals raised in $\mathrm{C}$-cages.

\section{Discussion}

\subsection{Rearing in floating cages}

Our previous work (Chim et al., 2007) showed that floating cages were a good tool for shrimp culture study in earthen ponds., allowing the shrimps to be fully reared up to the commercial size, with zootechnical results lying within the standard ranges for the New Caledonian farms (GFA, 2006).

In the present study, the main advantage was to allow shrimps to be reared in the same environment, so that the differences between treatments could be unambiguously attributable to the probiotic effect. Another advantage was the enhanced statistical power of the results through the increased number of replicates in comparison with studies carried out directly in earthen ponds (Chim et al., 2007). 


\subsection{Probiotic effects on survival, FCR and nutritional status}

The low survival rates obtained in ponds $A$ and $B$ were in accordance with previous results from the farm, and can be related to Summer Syndrome (Goarant et al., 2006). This septicaemic vibriosis was first identified in 1997 in the present shrimp farm, and since the final survival rates obtained have varied between $22 \%$ and 38\%, depending on the year (Lemonnier et al., 2006). Results of rearing in our floating cage conditions without using probiotics led to similar results, with survival rates of $31.1 \pm 1.5$ and $37.8 \pm 19$ for ponds $A$ and $B$ respectively. The increase in the mortality curve, during the first two weeks after stocking the cages, closely parallels the load curve of $\mathrm{V}$. nigripulchritudo in the haemolymph of the animals over the same period. Prevalence also seems to be strongly linked to the mortality curve, with a slight shift as previously reported by Goarant et al. (2006). These authors suggested the existence of a latency phase for this disease. We also found a correlation $(r=0.86$, $\mathrm{P}<0.001$ ) between the prevalence of $\mathrm{V}$. nigripulchritudo and the fall in temperature for control animals in cages and animals raised directly in the pond. This result may suggest the importance of water temperature for this disease. We observed that treatment with probiotic $P$. acidilactici significantly improved the survival of the shrimp in pond $A(+7 \%)$ and pond $B(+15 \%)$. Interestingly, our data also revealed a reduction of $\mathrm{V}$. nigripulchritudo prevalence and load levels in shrimps fed with the probiotic within the first two weeks of the trial, during which these variables reached maximum values for control animals. Explanation of this result may involve the direct or indirect effects of the probiotic strain on the associated microbiota of the shrimp by specific or unspecific mechanisms, which in turn may limit the effect of some pathogenic strains.

The probiotic treatment also improved final biomass $(P=0.09)$ and significantly reduced the food conversion ratio. In situ studies of LABs application on aquatic species, and more specifically on shrimp species, are scarce and arguments to explain relative effects are sometimes missing. Venkat et al. (2004) showed that strains of Lactobacillus acidophilus and L. sporogenes significantly improved growth of Macrobrachium rosenbergii postlarvae. However, survival was not affected in this case. The same authors observed inhibitory effects of the LABs tested against the gram negative flora present in the fresh water of the shrimp's gut. The positive effect of probiotic in FCR has also been already pointed out in Penaeus indicus larvae fed with L. plantarum (Uma et al., 1999).

The hepatopancreas is considered to be the main storage organ in shrimp, mainly accumulating lipids (Luvizotto-Santos et al., 2003). In the course of our study we showed in sub-adult animals (mean weight $>10 \mathrm{~g}$ ), which have different feeding habits and diet than juveniles (Nunes and Parson, 2000), that the hepatosomatic index (HSI) values were significantly higher for treated shrimps. The same trend was observed for the adjusted hepatopancreas dry weight, which was then significantly $(P<0.05)$ higher in shrimps receiving probiotic the last two weeks of rearing. Adjusted dry weight is a very simple and specific indicator of the state of hepatic reserves (unpublished data). Variations of hepatopancreas adjusted dry weight are probably due to variations in the lipid content (Sánchez-Paz et al., 2007). Several hypotheses could explain the effect of probiotic on hepatic reserves. The storage status at a given moment is an equilibrium resulting from the deposition of nutriments in the hepatopancreas and its utilization for the energetic needs and biosynthesis of the animal. In this case, the probiotic could have modulated either the storage process of nutriments, or their use, or both simultaneously. Additional results on trypsin and a amylase activity in the digestive gland showed that enzyme activity significantly increased after the first meal (8am). However, this phenomenon was not obvious after the second feeding (3pm). Previous studies on Penaeus kerathurus and Palaemon squilla showed that both amylase and trypsin activity is influenced by feeding and by the circadian rhythm (Van Wormhoudt et al., 1972; Trellu and Ceccaldi, 1977). For instance, Van Wormhoudt et al. (1972) showed successive significant rises in trypsin and amylase activity at both 10am and 10pm independently of feeding. Thus the rise of enzyme activity following the first meal in the present study could result from a combination of factors, such as the circadian rhythm, no feeding during the night (15 hours), and re-feeding. The absence of the same rise in enzyme activity following the second meal could be explained either by the interaction of the effects of food intake or by the nictemeral cycle and by the short daily intermeal period ( 7 hours). Administration of the probiotic modified enzymatic activity in the digestive gland at both levels: (i) higher basic total and specific activity of $\alpha$ amylase and trypsin (animal unfed for 16 hours), (ii) shorter postprandial peaks of enzyme activity following the morning meal while enhancing the trypsin total activity peak. Those results are difficult to compare with those of the literature, which provides very little information on the kinetics of digestive enzyme activity following feeding under pond rearing conditions. On this topic, we can cite the work of Muhlia-Almázan and García-Carreño (2002), who followed digestive enzyme activity in Penaeus vannamei on the basis of moulting stages and the duration of starvation. In the present study, we did not determine whether the modulation of enzymatic activity observed in the probiotic group is due to a direct effect of the 
strain or to an indirect effect. Because gram-positive bacteria secrete a wide range of exoenzymes, it is difficult to distinguish activity due to the enzymes synthesized by the shrimp from activity due to the enzymes synthesized by the bacteria. However, total higher trypsin and amylase activity of treated shrimps before feeding was measured while the concentration of $P$. acidilactici was putatively close to 0 . This suggests that the exogenous enzymes produced by the probiont account for only a small proportion of total enzyme activity. It is possible that the probiotic may in some way stimulate endogenous enzymes produced by the shrimp. Ingestion of food is considered by Head and Conover (1983) to be the main factor affecting the enzyme secretion in copepods. Therefore those results may also be a consequence of feed intake stimulation by the probiotic treatment. This hypothesis remains to be investigated more fully.

We assume that probiotic treatment might have led to enhanced digestion and increased absorption of food, which in turn contributed to improving hepatic storage in the digestive gland and the feed conversion ratio (FCR) observed in L. stylirostris.

\subsection{Probiotic pattern in the digestive tract}

It is commonly accepted that lactic bacteria are naturally present in the digestive tract of fish (Ringø and Gatesoupe, 1998). However, most studies on the intestinal microflora of shrimps, and more generally of crustaceans, do not report the presence of lactic bacteria in their digestive tract (Dempsey et al., 1989; Harris, 1993, Oxley and Shipton, 2002; Venkat et al., 2004). Cai et al. (1999) report the presence of three bacterial species, Lactococcus garvieae, Pediococcus acidilactici, and Enterococcus faecium, in the gut of the freshwater shrimp Macrobrachium rosenbergii. In our study, bacterial counts on MRS (specific medium to LAB) in the gut of control animals do not indicate the natural presence of lactic acid bacteria at any time during the trial. Only the probiotic strain (grey-white to yellowish-white colonies, round shaped and with a smooth surface with diameters between 1 to $2.5 \mathrm{~mm}$ ) has been recorded as lactic acid bacteria in the intestine of shrimp receiving dietary probiotic. This suggests that the strain survives and withstands the conditions of the shrimp digestive tract, which is an important feature, since it is accepted that probiotic activity is often linked to the supposed viability of the strain inside the digestive tract of the host (Panigrahi et al., 2005). Previous results in tanks with clear water showed that P. acidilactici administered at a concentration close to $10^{7} \mathrm{CFU} . \mathrm{g}^{-1}$ of feed was retrieved around $5 \times 10^{4} \mathrm{CFU} \cdot \mathrm{g}^{-1}$ of fresh gut (unpublished data). In the present study an average concentration of $1.3 \times 10^{4} \mathrm{CFU} \cdot \mathrm{g}^{-1}$ was recorded two hours after administration. The lower concentrations retrieved in the present study could be explained by the occurrence of natural food available in cages that contributes to the whole diet of the shrimp and dilutes the probiotic provided only through the pelleted feed. Basically, the probiotic concentrations in the gut recorded in our study are in the same range as those reported for other probiotics used for shrimp applications. Rengpipat et al. (2000) showed on Penaeus monodon, that the concentration of probiotic Bacillus S11 reached mean levels of $10^{6} \mathrm{CFU} \cdot \mathrm{g}^{-1}$ of gut when administered doses in food ranged between $1.3910^{10}$ and $4.6910^{10} \mathrm{CFU}^{-1}$. More recently, Ziaei-Nejad et al. (2006) showed that commercial Bacillus reached concentrations ranging between $10^{4}$ and $10^{5} \mathrm{CFU} \cdot \mathrm{g}^{-1}$ of digestive tract when it was applied in water with $10^{7}$ CFU.ml ${ }^{-1}$. Regarding lactic acid bacteria, few examples of their use as probiotics on shrimps are available and the count of the probiotic strain in the digestive tract of the animals has not been systematically reported (Venkat et al., 2004). In our study, P. acidilactici concentration two hours after the meal reaches the same level throughout the trial. The probiotic concentration remains above $5 \mathrm{x}$ $10^{3} \mathrm{CFU} \cdot \mathrm{g}^{-1} 4$ hours after feeding, and then decreases gradually to reach values around $2 \times 10^{3} \mathrm{CFU} \cdot \mathrm{g}^{-}$ ${ }^{1}$ after 6 hours. These trends indicate that the probiotic strain must be transient, and may not adhere to the intestinal mucous of L. stylirostris. This result confirms studies carried out on fish reviewed by Ringø and Gatesoupe (1998), who reported that lactic acid bacteria managed via food generally do not colonize the intestinal mucous and are lost during the intestinal transit within a few days after their ingestion. This has been confirmed by Aubin et al. (2005), who showed that the same strain of P. acidilactici was only retrieved at low concentration $<10^{2} \mathrm{CFU} \cdot \mathrm{g}^{-1}$ in the intestine of rainbow trout unfed for 20 hours. The authors stated then that the probiotic was transient without noticeable mucosal association. The short intestine and fast transit time of shrimp (Dall, 1967) could explain the faster disappearance of the probiotic in comparison with fish. Moreover, the intestinal transit time of shrimp, and particularly of L. stylirostris, is affected by water temperature, since the time between two meals (refractory period) is inversely proportional to temperature (Chim et al., 2004). This could explain why $P$. acidilactici colonies were recorded up to 16 hours after the last feeding, when pond water temperatures fell to the low threshold $\left(21^{\circ} \mathrm{C}\right.$ ) of $\mathrm{L}$. stylirostris thermal preferendum (Wabete et al., in press). The results suggest a relationship between the presence of the probiotic in the digestive tract 
and the speed of intestinal transit, which is itself highly correlated with temperature. In practice, this suggests that it may be necessary to provide probiotic more frequently to compensate for its elimination. The two feed distributions made during this study did not allow the probiotic at concentration around $10^{4} \mathrm{CFU} . \mathrm{g}^{-1}$ of gut to be retrieved more than $40 \%$ of the time. Under these conditions, the probiotic action could probably be effective only at the times of its optimal concentration in the digestive tract. Further investigation in this area would be necessary to specify the programme for administering the probiotic.

\subsection{Probiotic effect on the associated microflora of $L$. stylirostris digestive tract.}

The results show that the probiotic had an effect on the microflora of the digestive tract of the shrimp. The effect was one of lower bacteria concentrations, including vibrio, in the gut of treated animals, and was most pronounced when the highest level of P. acidilactici were recorded in the gut ( 2 to 4 hours after feeding). This significant limitation of bacterial load after feeding probiotic, compared to the control, indicates that the strain tested might have in vivo bacteriostatic properties. These results are consistent with previous data (unpublished) showing an in vitro antagonistic effect of $P$. acidilactici strain MA 18/5 M against several Gram-positive and Gram-negative bacteria, and notably towards some Vibrios strains pathogenic to L. stylirostris.

Results of the follow-up over one day of rearing confirmed this significant limitation of bacterial load after delivering the probiotic and showed variation of this effect over the time period. Modulation of the probiotic effect during the day may be related to the different levels of $P$. acidilactici recorded in the gut over the same period. Such kinetics would need to be confirmed and the study probably extended to 24 hours, as well as being repeated with additional experiments, notably on the putative effects of probiotic feeding frequency.

Antimicrobial effects of bacteria generally come from the following substances released alone or in association: antibiotics, bacteriocins, siderophores, lysozymes, proteases, hydrogen peroxide or organic acids degrading the $\mathrm{pH}$ of the medium, and ammonia and diacethyl. It is commonly accepted that the primary effects exerted by LABs are reduction of $\mathrm{pH}$ and removal of carbohydrates (Daeshel, 1989). It is also accepted that the probiotic effects of many LABs forms are based on the production of diverse antibacterial metabolites (bacteriocins in particular). Various authors have stated that among extracellular substances produced by probiotics, bacteriocins would be the most important (Gildberg et al., 1997). Bacteriocins (pediocin) are excreted by some strains of P. acidilactici (Bhunia et al., 1990; Cintas et al., 1995, Mora et al., 2002). It can therefore be hypothesised that the Pediococcus strain studied here may produce such substances which modify the intestinal microflora of shrimp. However, this hypothesis has to be tempered, since it is generally agreed that bacteriocins are peptides which are effective mostly against bacteria closely related to the producing strain (Gatesoupe, 1999; Guerra and Pastrana, 2003). The P. acidilactici strain tested was also selected for its capacity to produce large quantities of lactic acid. Lactic and acetic acids produced by lactic fermentations of LAB are able to acidify bacteria interior leading to the expulsion of $\mathrm{H}+$ ions from the cells and causing uncoupling of the Na+ - K+ (ATPase) pump (Goncalves et al., 1997). Ringø and Gatesoupe (1998) stated that bacteria capable of producing lactic acid fermentation may inhibit the proliferation of putrefactive microbes in the digestive tract of aquatic organisms and thus contribute to improved health status of the host. Further, the release of lactic acid resulting in modifications of the gut's pH may be another factor accounting for the effect observed in its microflora. Vázquez et al. (2005) showed, for instance, that lactic and acetic acids are responsible for the effects of nine potential lactic acid bacteria probiotics tested for their inhibitory effects on four common pathogens of turbot.

At this stage of knowledge, both production of bacteriocins and/or acidification by lactic acid seem to be consistent hypotheses, and could explain the action of the probiotic on the gut microflora. However, as emphasized by Aubin et al. (2005), the probiotic effect of this strain could be either direct, because of bacteriostatic properties, or indirect, by stimulating favourable intestinal microbiota. Furthermore, the specific action mechanisms of probiotic activity, both in terrestrial animals and for human applications, are probably of a very diverse nature and the effects are unlikely to arise from independent mechanisms. A combination of several action mechanisms is probably involved, which makes their in vivo demonstration harder (Gatesoupe, 1999). In the present instance, we cannot say at this stage whether the observed action is specifically directed towards any bacterial communities and correlated with the effects observed on V. nigripulchritudo records in the haemolymph. The use of methods targeting specific bacterial strains (i.e. pathogenic strains) or giving a representative overview of the bacterial community in the gut and haemolymph (TTGE or DGGE) may be helpful in progressing further in this investigation. 


\section{Conclusion}

Under our experimental conditions, the probiotic P. acidilactici acted favourably on the survival and FCR of the shrimp L. stylirostris. Although we are not able to clarify the mechanisms involved, the probiotic treatment brought about significant antagonistic activity toward the microflora of the digestive tract and led to the reduction of prevalence and load of $\mathrm{V}$. nigripulchritudo, which has been involved in serious outbreaks in New Caledonia. In nutritional terms, sub-adult L .stylirostris $(>10 \mathrm{~g})$ presented higher hepatic storage when fed with the probiotic, and basic digestive enzyme activities were enhanced by the treatment. We assume that this result may be related to better feed utilisation by animals given the probiotic diet.

Under our feeding conditions, the probiotic concentration in the gut was found to be highly variable, suggesting a possible improvement and optimization of the treatment by adjusting probiotic feeding frequency. Indeed, we assume that it should be possible to strengthen the probiotic effect by increasing the residence time of the strain in the digestive tract.

Our future research on this topic will need to pay attention to optimizing probiotic dose and frequence for its application during various shrimp grow-out seasons. We shall also look at the qualitative effects of the probiotic strain on the bacterial community associated with the shrimp intestine and investigate more precisely the nutritional and potential physiological impact of such treatment.

\section{Acknowledgments}

This project is a part of a global and specific research programme set up by IFREMER to provide an overall explanation for vibriosis affecting shrimp farming in New Caledonia. The work was supported by research grants from the Northern and Southern Provinces of New Caledonia. The authors would like to thank Lallemand Animal Nutrition S.A. (Blagnac, France) for its collaboration by partly supporting the study and providing the probiotic. The authors would also like to thank all IFREMER zootechnical staff of the Département Aquacole en Calédonie who kindly helped us with the design, construction and set-up of the cages and the final harvesting. We also extend our thanks to the owners of the private farm and their employees for their assistance throughout the experiment.

\section{References}

Alavandi, S.V., Vijayan., K.K., Santiago, T.C., Poornima, M., Jithendran, K.P., Ali, S.A., Rajan, J.J.S., 2004. Evaluation of Pseudomonas sp. PM 11 and Vibrio fluvialis PM 17 on immune indices of tiger shrimp, Penaeus monodon. Fish \& Shellfish Immunology 17, 115-120.

Aubin, J., Gatesoupe, F.J., Labbe, L., Lebrun, L., 2005. Trial of probiotics to prevent the vertebral column compression syndrome in rainbow trout (Oncorhynchus mykiss Walbaum). Aquaculture Research 36, 758-767.

Baumann, P., Schubert, R.H.W., 1984. Section 5. Facultatively anaerobic Gram-negative rods, Family II. Vibrionaceae. In: Holt, J.G., Krieg, N.R. (Eds.), Bergey's Manual of Systematic Bacteriology, vol. 1. Williams \& Wilkins Co., Baltimore, MD, pp. 516- 550.

Bernfeld, P., 1955. Amylase. In: Colowick, S.P., Kaplan, N.O. (Eds.), Methods in Enzymology. Academic Press, New York, pp. 149-158.

Bhunia, AK., Johnson, M.C., Ray, B., Belden, E.L., 1990. Antigenic property of pediocin AcH produced by Pediococcus acidilactici. J. Appl. Bacteriol. 69, 211-215.

Bouyer, J., 1997. Méthodes statistiques: Médecine - Biologie. ESTEM, Editions INSERM, Paris, 351 pp.

Cai, Y., Suyanandana, P., Saman, P., Benno, Y., 1999. Classification and characterization of lactic acid bacteria isolated from the intestines of common carp and freshwater prawns. J. Gen. Appl. Microbiol, 45, 177-184.

Castex, M., Chim, L., Wabete, N., Lemaire, P., Usache, V., 2006. Feeding evaluation of probiotic bacteria Pediococcus acidilactici (Bactocell囚) in sub adult shrimp Litopenaeus stylirostris: microbial, nutritional and zootechnical aspects. In book of abstract WAS annual meeting, 9-13 may 2006. Florenze, Italia.

Chim, L., Galois, R., Martin, J.L.M., Lemaire, P., Wabete, N., Massabuau, J.C., Cuzon, G., 2004. Influence de la température sur quelques aspects de la nutrition de Litopenaeus stylirostris. Conséquences sur la formulation et la distribution de l'aliment en fonction de la saison d'élevage. In: Styli 2003. Trente ans de crevetticulture en Nouvelle-Calédonie (Ed. Ifremer), Actes Colloq. 99-105. 
Chim L., Maisonneuve, V., Lemaire, P., Wabete, N., Usache, V., 2005. Dietary probiotic Pediococcus acidilactici MA 18/5 (Bactocell $®$ ) study to a juvenile marine shrimp Litopenaeus stylirostris reared in tanks and in pond. In book of abstracts. WAS annual meeting. 9-13 may 2005. Bali, Indonesia.

Chim, L., Castex, M., Wabete, N., Lemaire, P., Pham, D., Brun, P., 2007. Development of an original tool for shrimp culture studies using floating cages in earthen pond. First trial carried out to evaluate lactic acid probiotic (Bactocell $®$ ) in shrimp Litopeneus stylirostris reared in comercial farm subject to vibriosis. In book of abstract Asian Pacific Aquaculture, 5-8 august 2007. Hanoi, Vietnam.

Cintas, L.M., Rodriguez, J.M., Fernandez, M.F., Sletten, K., Nes, I.F., Hernandez, P.E., Holo H., 1995. Isolation and characterization of pediocin L50, a new bacteriocin from Pediococcus acidilactici with a broad inhibitory spectrum. Appl Environ Microbiol. 61, 2643-2648.

Daeshel, M.A., 1989. Antimicrobial substances from lactic acid bacteria for use as food preservatives. Food Technol. 43, 164-167.

Dall, W., 1967. The functionnal anatomy of the digestive tract of a shrimp Metapenaeus bennettae (Racek \& Dall). Aust.J. Zool. 15, 699-714.

Dempsey, A.C., Kitting, C.L., Rosson, R.A., 1989. Bacterial variability among individual peneid shrimp digestive tracts. Crustaceana. Vol. 56, no. 3, pp. 267-278.

Drach P., Tchernifovtzeff, C., 1967. Sur la méthode de détermination des stades d'intermue et son application générale aux crustacés. Vie Milieu 18, 596-609.

Erlanger, B.F, Kokowsky, N., Cohen, W., 1961. The preparation and properties of two chromogenic substrates of trypsin. Arch. Biochem. Biophys. 95, 271-278.

Fernández, I., Oliva, M., Carrillo, O., Van Wormhoudt, A., 1997. Digestive enzyme activities of Penaeus notialis during reproduction and moulting cycle. Comp. Biochem. Physiol. 118A, 1267-1271.

García-Carreño F.L., Hernández-Cortés, M.P., Haard, N.F., 1994. Enzymes with peptidase and proteinase astivity from the digestive systems of a freshwater and a marine decapod. J. Agric. Food. Chem. 42, 1456-1461.

Garriques, D., Arevalo. G., 1995. An evaluation of the production and use of a live bacterial isolate to manipulate the microbial flora in the commercial production of Penaeus vannamei postlarvae in Ecuador. In: C. L. Browdy and J. S. Hopkins (ed.), Swimming through troubled water. Proceedings of the Special Session on Shrimp Farming, Aquaculture '95. World Aquaculture Society, Baton Rouge, La, pp. 53-59.

Gatesoupe, F. J., Arakawa, T., Watanabe, T., 1989. The effect of bacterial additives on the production rate and dietary value of rotifers as food for Japanese flounder, Paralichthys olivaceus. Aquaculture 83, 39-44.

Gatesoupe, F. J., 1991. The effect of three strains of lactic bacteria on the production rate of rotifers, Brachionus plicatilis, and their dietary value for larval turbot, Scophthalmus maximus. Aquaculture 96, 335-342.

Gatesoupe, F. J., 1994. Lactic acid bacteria increase the resistance of turbot larvae, Scophthalmus maximus, against pathogenic Vibrio. Aquat. Living Resour. 7, 277-282.

Gatesoupe, F.J., 1999. The use of probiotics in aquaculture. Aquaculture 180, 147-165.

Gatesoupe, F.J., 2002a. Probiotic and formaldehyde treatments of Artemia nauplii as food for larval pollack, Pollachius pollachius. Aquaculture 21, 347-360.

Gatesoupe, F.J., 2002b. Les probiotiques pour poissons: "sur mesure" ou "prêt-à-traiter" ?. In: 7ème Bordeaux Aquaculture, 4ème Journée de la Nutrition, 20 September 2002, pp. 13-16.

GFA., 2006. Rapport d'activité : missions et analyses de l'observatoire technique et de l'observatoire économique. Groupement des fermes aquacoles de Nouvelle-Calédonie, Noumea, 72 pp.

Gildberg, A., Johansen A., Bogwald, J., 1995. Growth and survival of Atlantic salmon (Salmo salar) fry given diets supplemented with fish protein hydrolysate and lactic acid bacteria during a challenge trial with Aeromonas salmonicida. Aquaculture 138, 23-34.

Gildberg, A., Mikkelsen, H., Sandaker, E., Ringø, E., 1997. Probiotic effect of lactic acid bacteria in the feed on growth and survival of fry of Atlantic cod Gadus morhua. Hydrobiologia 352, 279-285.

Goarant, C., Ansquer, D., Herlin, J., Domalain, D., Imbert, F., De Decker, S., 2006. Summer Syndrome in Litopenaeus stylirostris in New Caledonia: Pathology and epidemiology of the etiological agent, Vibrio nigripulchritudo. Aquaculture 253, 105- 113.

Gomez-Gil, B., Roque, A., Turnbull, J., 2001. The use and selection of probiotic bacteria for use in the culture of larval aquatic organisms. Aquaculture 191,259-270.

Goncalves, L.M.D., Ramos, A., Almeida, J.S., Xavier, A.M.R.B., Larrondo, M.J.T., 1997. Elucidation of the mechanism of lactic acid growth inhibition and production in batch cultures of Lactobacillus rhamnosus. Appl. Microbiol. Biotechnol. 48, 346-350.

Guerra, N.P., Pastrana, L., 2003. Influence of $\mathrm{pH}$ drop on both nisin and pediocin production by Lactococcus lactis and Pediococcus acidilactici. Letters in Applied Microbiology 37, 51-55. 
Haard, N. F., Dimes, L. E., Arndt, R. E., Dong, F. M., 1996. Estimation of Protein Digestibility IV. digestive proteinases from the pyloric caeca of Coho salmon (Oncorhynchus kisutch) fed diets containing Soybean Meal. Comp. Biochem. Physiol. 115B, 533-540.

Harris, J.M., 1993. The Presence, Nature, and Role of Gut Microflora in Aquatic Invertebrates: A Synthesis. Microb Ecol. 25:195-231.

Head, E.J.H., Conover, R.J., 1983. Induction of digestives enzymes in Calanus hyperboreus. Mar.Biol.Lett. 4, 219-231.

Irianto, A., Austin, B., 2002. Review Probiotics in aquaculture. J. Fish Dis. 25, 633.

Le Groumellec, M., Goarant, C., Haffner, P., Berthe, F., Costa, R., Mermoud, I., 1996. Syndrome 93 in New Caledonia: Investigation of the bacterial hypothesis by experimental infections, with reference to stress-induced mortality. SICCPPS book of abstracts, SEAFDEC, lloilo City, Philippines, p. 46.

Lemonnier, H., Herbland A., Salery, L., Soulard, B., 2006. "Summer syndrome” in Litopenaeus stylirostris grow-out ponds in New Caledonia: Zootechnical and environmental factors. Aquaculture 261, 1039-1047.

Lightner, D.V., 1988. Vibrio disease of penaeid shrimp. In: Sindermann, C.J., Lightner, D.V. (Eds.), Disease Diagnosis and Control in North American Marine Aquaculture. Elsevier, Amsterdam, The Netherlands, pp. 42- 47.

Lin, C.K., 1995. Progression of intensive marine shrimp culture in Thailand. In: C. L. Browdy and J.S. Hpkins (ed.), Swimming through troubled water. Proceedings of the special Session on Shrimp farming, Aquaculture' 95. World Aquaculture Society, Baton Rouge, La, pp. 13-23.

Lowry O., Rosebrough, N.J., Farr, AL., Randall, R.S., 1951. Protein measurements with Folin phenol reagent. J. Biol. Chem. 193, 265-275.

Luvizotto-Santos, R., Lee, J.T., Pereira-Branco, Z., Bianchini, A., Maia-Nery, L.E., 2003. Lipids as energy source during salinity acclimation in the euryhaline crab Chasmagnathus granulate Dana, 1851 (Crustacea-Grapsidae). J. Exp. Zool. 295A, 200-205.

Mora, D., Parini, C., Fortina, M.G., Manachini, P.L., 2002. Multilocus hybridization typing in Pediococcus acidilactici strains. Current Microbiology 44,77-80.

Moriarty, D.J.W., 1998. Control of luminous Vibrio species in penaeid aquaculture ponds. Aquaculture 164, 351-358.

Moriarty, D.J.W., 1999. Disease control in shrimp aquaculture with probiotic bacteria. Proceedings of the 8th International Symposium on Microbial Ecology, Atlantic Canada Society for Microbial Ecology, Halifax, Canada, pp 237-243.

Muhlia-Almazán, A., García-Carreño, F.L., 2002. Influence of moulting and starvation on the synthesis of proteolytic enzymes in the midgut gland of the white shrimp Penaeus vannamei. Comp. Biochem. Physiol. 133B, 383-394.

Nikoskelainen, S., Ouwehand, A.C., Bylund, G., Salminen, S., 2001. Protection of rainbow trout Oncorhynchus mykiss from furunculosis by Lactobacillus rhamnosus. Aquaculture 198, 229-236.

Nunes, A.J.P., Parsons, G.J., 2000. Size-related feeding and gastric evacuation measurements for the Southern brown shrimp Penaeus subtilis, Aquaculture 187, 133-151.

Oxley, A., Shipton, W., 2002. Bacterial flora from the gut of the wild and cultured banana prawn, Penaeus merguiensis. J. Appl. Microbiol. 93, 214-223.

Panigrahi, A., Kirona, V., Puangkaewa, J., Kobayashib, T., Satoha,, S., Sugitac, H., 2005. The viability of probiotic bacteria as a factor influencing the immune response in rainbow trout Oncorhynchus mykiss. Aquaculture 243, 241- 254.

Planas, M., Vazquez, J.A., Marques, J., Perez-Lomba, R., Gonzalez, M.P., Murado, M., 2004. Enhancement of rotifer Brachionus plicatilis growth by using terrestrial lactic acid bacteria. Aquaculture 240, 313-329

Rengpipat, S., Rukpratanporn, S., Piyatiratitivorakul, S., Menasaveta, P., 2000. Immunity enhancement in black tiger shrimp Penaeus monodon by a probiont Bacillus S11. Aquaculture 191, 271-288.

Ringø, E., Gatesoupe, F.J., 1998. Lactic acid bacteria in fish: A review. Aquaculture 160, 177-203.

Sakata, T., 1989. Microflora of healthy animals. In: B. Austin and D.A. Austin (eds.), Methods for the biological examination of fish and shellfish. Ellis Horwood Ltd., West Sussex, England, PP. 141-163.

Sánchez-Paz, A., García-Carreño, F., Hernández-López, J., Muhlia-Almazán, A., Yepiz-Plascencia, G., 2007. Effect of short-term starvation on hepatopancreas and plasma energy reserves of the Pacific white shrimp (Litopenaeus vannamei). J. Exp. Marine Bio. 340, 184- 193.

Sokal, R.R., Rohlf, F.J., 1995. Biometry: the principles and practice of statistics in biological research. 3rd edition. W. H. Freeman and Co., New York, 887 pp.

Strøm, E., Ringø, E., 1993. Changes in the bacterial composition of early developing cod, Gadus morhua (L.) larvae following inoculation of Lactobacillus plantarum into the water. In: B. T. Walther, 
and H. J. Fyhn (ed.), Physiological and biochemical aspects of fish development. University of Bergen, Bergen, Norway, pp. 226-228.

Trellu, J., Ceccaldi, H.J., 1977. Circadian variations of some enzymatic activities in Palaemon squilla Linné (1758) (Crustacea, Decapoda). J. interdiscipl. Cycle Res. 8, 357- 359.

Uma, A., Abraham, T.J., Sundararaj, V., 1999. Effect of a probiotic bacterium, Lactobacillus plantarum on disease resistance of Penaeus indicus larvae. Indian Journal of Fisheries 46, 367-373.

Van Wormhoudt, A., Ceccaldi, J.H., Le Gal, Y., 1972. Activité des protéases et amylases chez Penaeus kerathurus : existence d'un rythme circadien. C. R. Acad. Sc. Paris, D, 274, 1208-1211.

Vandenbergh, P., 1993. Lactic acid bacteria, their metabolic products and interference with microbial growth. FEMS Microbiol. Rev. 12, 221-238.

Vaseeharan, B., Ramasamy, P., 2003. Control of pathogenic Vibrio spp. by Bacillus subtilis BT23, a possible probiotic treatment for black tiger shrimp Penaeus monodon. Lett. Appl. Microbiol. 36, 83-87.

Vázquez, J.A., González, M.P., Murado, M.A., 2005. Effects of lactic acid bacteria cultures on pathogenic microbiota from fish. Aquaculture 245, 149- 161.

Venkat, H.K., Sahu, N.P., Jain, K.K., 2004. Effect of feeding Lactobacillus-based probiotics on the gut microflora, growth and survival of postlarvae of Macrobrachium rosenbergii (de Man). Aquaculture Research 35, 501-507.

Vershuere, L., Rombaut, G., Sorgeloos, P., Verstraete, W., 2000. Probiotic bacteria as biological control agents in aquaculture. Microbiol. Mol. Biol. Rev. 64, 655-671.

Vijayan, K.K, Bright Singh, I.S., Jayaprakash, N.S., Alavandi, S.V., Somnath Pai, S., Preetha R., Rajan J.J.S., Santiago, T.C., 2006. A brackishwater isolate of Pseudomonas PS-102, a potential antagonistic bacterium against pathogenic vibrios in penaeid and non-penaeid rearing systems. Aquaculture 251, 192-200.

Villamil, L., Tafalla, C., Figueras, A., Novoa, B., 2002. Evaluation of Immunomodulatory Effects of Lactic Acid Bacteria in Turbot (Scophthalmus maximus). Clinical and diagnostic laboratory of immunology 9, 1318-1323.

Vine, N.G., Leukes, W.D., Kaiser, H., 2006. Probiotics in marine larviculture. FEMS Microbiol. Rev. 30, 404-427.

Wabete, N., 2005. Etude écophysiologique du métabolisme respiratoire et nutritionnelle chez la crevette peneide Litopeneaus stylirostris. Application à la crevetticulture en Nouvelle Calédonie. Thèse présentée à l'Université Bordeaux 1. Ecole doctorale Sciences du vivant, Géosciences et Sciences de l'Environnement. 173 p.

Wabete N., Chim L., Lemaire P., Massabuau J.C. Life on the edge: physiological problems in penaeid prawns Litopenaeus stylirostris, living on the low side of their thermopreferendum. Marine Biology (in press).

Ziaei-Nejad S., Rezaei, M.H., Takami, G.A., Lovett, D.L., Mirvaghefi, A., Shakouri, M. , 2006. The effect of Bacillus spp. bacteria used as probiotics on digestive enzyme activity, survival and growth in the Indian white shrimp Fenneropenaeus indicus. Aquaculture 252, 516-524.

\section{Tables}

Table 1. Experimental design

\begin{tabular}{ccccc}
\hline Pond & $\begin{array}{c}\text { Rearing period } \\
\text { (number of days })\end{array}$ & $\begin{array}{c}\text { Number of } \\
\text { cages }\end{array}$ & Treatment & $\begin{array}{c}\text { Shrimps per } \\
\text { cage }\end{array}$ \\
\hline Pond A & $\begin{array}{c}28 / 03 / 06 \text { to 08/06/06 } \\
(73 \text { days })\end{array}$ & 5 & Control & 400 \\
& & 5 & Probiotic & 400 \\
Pond B & $\begin{array}{c}29 / 03 / 06 \text { to 08/06/06 } \\
(72 \text { days })\end{array}$ & 5 & Control & 400 \\
& 5 & Probiotic & 400 \\
\hline
\end{tabular}


Table 2. Zootechnical results and significant differences in C-Cages (control) and P-Cages (probiotic treatment) in pond $A$ and B. ( \pm standard deviation, $n=5$; n.s., not significant; n.a., not applicable). *Different superscript letters within the same line indicate significant differences among treatments with pairwise LSD Fisher test.

\begin{tabular}{|c|c|c|c|c|c|}
\hline & \multicolumn{2}{|c|}{ Pond $\mathrm{A}$} & \multicolumn{2}{|c|}{ Pond B } & \multirow{2}{*}{$\begin{array}{l}\text { Significance fo } \\
\text { probiotic effect }\end{array}$} \\
\hline & C-cages & P-cages & C-cages & P-cages & \\
\hline Survival (\%) & $31.08 \pm 3.39^{\mathrm{a}}$ & $33.31 \pm 3.37^{\mathrm{a}}$ & $37.84 \pm 4.22^{\mathrm{b}}$ & $43.65 \pm 2.78^{c}$ & $P<0.001^{*}$ \\
\hline GR $\left.(\text { g.day })^{-1}\right)^{(1)}$ & $0.23 \pm 0.04^{\mathrm{a}}$ & $0.23 \pm 0.03^{\mathrm{a}}$ & $0.20 \pm 0.05^{\mathrm{b}}$ & $0.19 \pm 0.05^{\mathrm{b}}$ & $\mathrm{n} . \mathrm{s}^{\S}$ \\
\hline Final body weight (g) & $19.91 \pm 3.27^{\mathrm{a}}$ & $20.12 \pm 2.63^{\mathrm{a}}$ & $17.22 \pm 3.68^{\mathrm{b}}$ & $16.83 \pm 3.59^{b}$ & n.s $s^{\varepsilon}$ \\
\hline Final Biomass (g) & $2291 \pm 346^{\mathrm{a}}$ & $2484 \pm 271^{a b}$ & $2408 \pm 299^{\mathrm{ab}}$ & $2706 \pm 210^{b}$ & $\mathrm{P}=0.09^{f}$ \\
\hline $\mathrm{FCR}^{(2)}$ & $2.29 \pm 0.19^{\mathrm{a}}$ & $2.09 \pm 0.12^{\mathrm{ab}}$ & $2.28 \pm 0.13^{\mathrm{a}}$ & $2.05 \pm 0.13^{b}$ & $\mathrm{P}<0.05^{\S}$ \\
\hline
\end{tabular}

(1) Daily Growth Rate

(2) Food Conversion Ratio

* Khi square test

${ }^{E}$ One way ANOVA (treatment)

$\S$ Two-way ANOVA (Pond, Probiotic treatment)

Table 3. Adjusted hepatopancreas dry weight (least mean square) of animals reared in floating cages after 5, 7, 8 and 10 weeks, and significant differences among C-Cages (control) and P-Cages (probiotic treatment) ( \pm standard error, $n=30$; n.s., not significant).

\begin{tabular}{|c|c|c|c|}
\hline \multirow{2}{*}{ Week } & \multicolumn{2}{|c|}{ Hepatopancreas dry weight (mg) } & \multirow{2}{*}{$\begin{array}{c}\text { Differences among } \\
\text { treatments* }\end{array}$} \\
\hline & C-Cages & P-Cages & \\
\hline 5 & $288.8 \pm 11.1$ & $270.1 \pm 9.0$ & n.s \\
\hline 7 & $265.1 \pm 8.2$ & $268.1 \pm 8.4$ & n.s \\
\hline 8 & $244.9 \pm 8.3$ & $269.4 \pm 8.9$ & $P<0.05$ \\
\hline 10 & $284.1 \pm 15.4$ & $328.4 \pm 18.4$ & $P<0.05$ \\
\hline
\end{tabular}

${ }^{*}$ ANOVA with hepatopancreas wet weight use as covariable 
Table 4. Average bacterial counts of $P$. acidilactici in shrimp digestive tract pre- and post- feeding over 10 weeks of rearing in P-cages ( \pm standard deviation, $n=3$; n.d., not detected; n.s. not significant; n.a. not applicable).

\begin{tabular}{|c|c|c|}
\hline \multirow{2}{*}{ Rearing week } & \multicolumn{2}{|c|}{ P.acidilactici counts in shrimp gut (CFU.g-1) } \\
\hline & $\begin{array}{l}\text { Before morning } \\
\text { feeding }\end{array}$ & $\begin{array}{l}2 \text { hours post } \\
\text { feeding }\end{array}$ \\
\hline 1 & n.d. & $24267.8 \pm 13612.5$ \\
\hline 2 & n.d. & $5724.1 \pm 1410.6$ \\
\hline 3 & n.d. & $14438.0 \pm 3988.5$ \\
\hline 4 & n.d. & $5744.3 \pm 1004.0$ \\
\hline 5 & $284.9 \pm 28.7$ & $21925.9 \pm 11485.4$ \\
\hline 7 & $134.5 \pm 77.8$ & $14940.2 \pm 1342.4$ \\
\hline 8 & $26.8 \pm 1.1$ & $7268.4 \pm 351.1$ \\
\hline 10 & n.d. & $6123.8 \pm 321.0$ \\
\hline Significance* & n.a & n.s \\
\hline
\end{tabular}

${ }^{*}$ Kruskal-Wallis test

Table 5. Average bacterial counts of $\mathrm{P}$. acidilactici (on MRS) in digestive tract of shrimp sampled over 14 hours during the 65th day of rearing in P-cages (9th week) ( \pm standard error, n=3; "-" non achieved). * Different superscript letters indicate significant differences among day times (Fisher's Protected Least Significant Difference).

\begin{tabular}{ccc}
\hline Day Time & Feeding & $\begin{array}{c}\text { P.acidilactici counts in } \\
\text { shrimp gut }\left(\text { CFU.g }{ }^{-1}\right)\end{array}$ \\
\hline 7:00 AM & & 0 \\
8:00 AM & $X$ & - \\
10:00 AM & & $2.06 \pm 0.1710^{4 \mathrm{a}}$ \\
12:00 PM & & $6.95 \pm 0.3910^{3 \mathrm{~b}}$ \\
3:00 PM & $X$ & $2.64 \pm 1.4610^{3 \mathrm{c}}$ \\
5:00 PM & & $3.85 \pm 0.0510^{4 \mathrm{~d}}$ \\
7:00 PM & & $3.41 \pm 0.1110^{4} \mathrm{ad}$ \\
9:00 PM & $2.02 \pm 1.0010^{3 \mathrm{c}}$ \\
\hline
\end{tabular}


Table 6. Average bacterial counts (on Marine agar and TCBS) in shrimp guts sampled weekly before and after feeding in C-Cages ( \pm standard error, $n=21$; n.s. non significant). Different superscript letters within the same line indicate significant differences among treatments with pairwise LSD Fisher test $(P<0.05)$.

\begin{tabular}{lccc}
\hline \multicolumn{1}{c}{ Bacterial count } & Before feeding & After feeding & $\begin{array}{c}\text { Differences among } \\
\text { the week* }\end{array}$ \\
\hline $\begin{array}{l}\text { Total heterotrophic bacteria } \\
\text { (Marine agar) }\end{array}$ & $8.4 \pm 1.4 .10^{9}$ a & $7.5 \pm 1.310^{9}$ a & n.s \\
Vibrio (TCBS) & $7.5 \pm 1.6 .10^{6}$ a & $1.1 \pm 0.3710^{7}$ a & $P<0.05$ \\
\hline
\end{tabular}

${ }^{\star}$ ANOVA (Log(CFU.g $\left.{ }^{-1}\right)$

Table 7. Correlation coefficients and correlation tests (Z-test) between the water temperatures in pond and the prevalence and load of $\mathrm{V}$. nigripulchritudo in the haemolymph of shrimp reared respectively in Ponds, C-Cages and P-Cages.

\begin{tabular}{ccccc}
\hline \multirow{2}{*}{$\begin{array}{c}\text { Rearing } \\
\text { condition }\end{array}$} & \multicolumn{4}{c}{ Correlation with water temperature } \\
\cline { 2 - 5 } & \multicolumn{2}{c}{ V.nigripulchritudo Prevalence } & \multicolumn{2}{c}{ V.nigripulchritudo Load } \\
\cline { 2 - 5 } & correlation $(r)$ & Z-test & correlation $(r)$ & Z-test \\
\hline Ponds & 0.87 & ${ }^{*} \mathrm{P}<0.001$ & 0.496 & $\mathrm{P}=0.18$ \\
C-cages & 0.86 & ${ }^{*} \mathrm{P}<0.001$ & 0.52 & $\mathrm{P}=0.16$ \\
P-cages & 0.342 & $\mathrm{P}=0.425$ & 0.315 & $\mathrm{P}=0.46$ \\
\hline
\end{tabular}




\section{Figures}

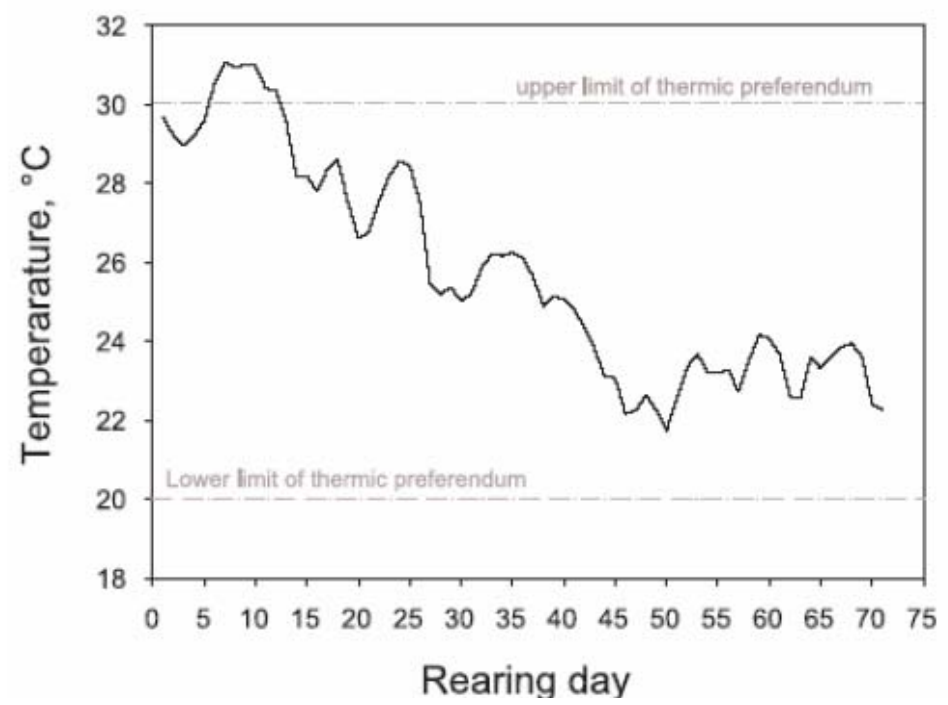

Figure 1. Mean water temperature in pond $A$ and $B$ of the farm during the period of the experiment. Upper and lower limits of L. stylirostris thermal preferendum are indicated in grey medium dash lines.

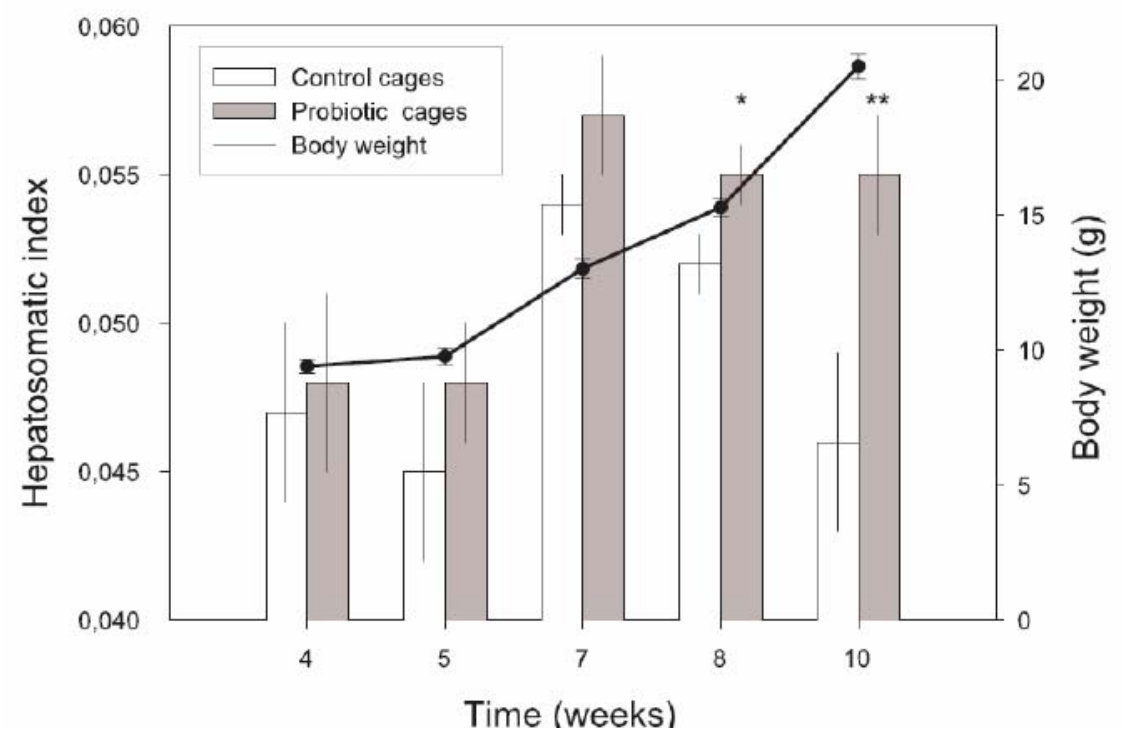

Figure 2. Hepatosomatic index, one hour before morning meal, and body weight of sampled shrimps at $4,5,7,8$ and 10 weeks of rearing in floating cages for control and probiotic treatments. Error bars indicate SD $(n=15) .\left(^{*}\right)$ indicate significant differences between treatment calculated with pairwise LSD Fisher test $\left({ }^{\star} \mathrm{P}<0.05 ;{ }^{*} \mathrm{P}<0.01\right)$. 

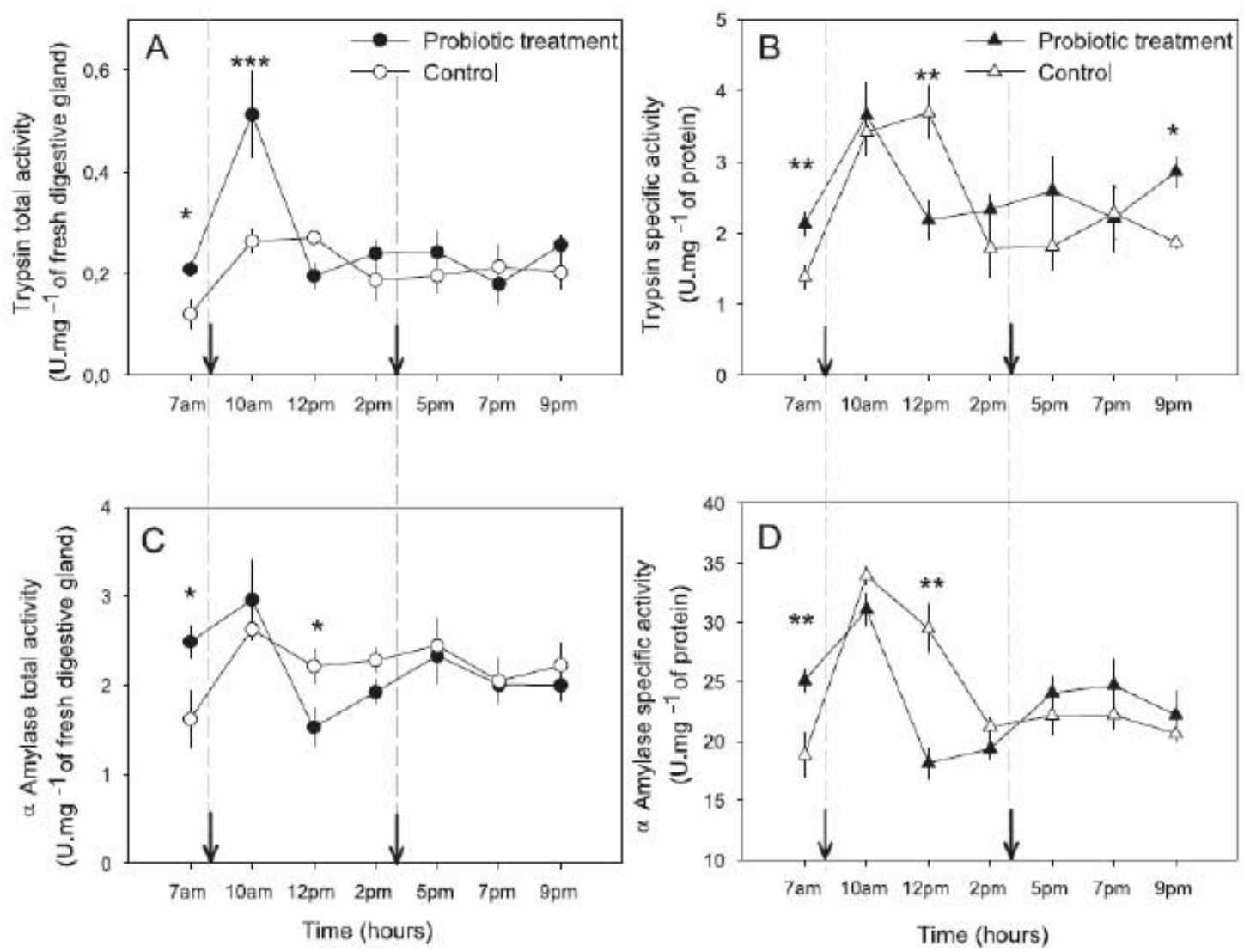

Figure 3. The effect of probiotic treatment on daily (from 7am to 9pm) trypsin and a amylase activities in the digestive gland of L.stylirostris during the 65th day of rearing in floating cages. A\&B. Total (U. mg-1 digestive gland) and specific (U.mg-1 protein) trypsin activities. C\&D. Total (U. mg-1 digestive gland) and specific (U.mg-1 protein) $\alpha$ amylase activity. Error bars indicate SD $(n=5)$. Superscript stars within the same sample time indicate significant differences among treatments with pairwise LSD Fisher $\left({ }^{\star} \mathrm{P}<0.05 ;{ }^{* *} \mathrm{P}<0.01,{ }^{* \star *} \mathrm{P}<0,001\right)$. Dark arrows indicate feeding time. 

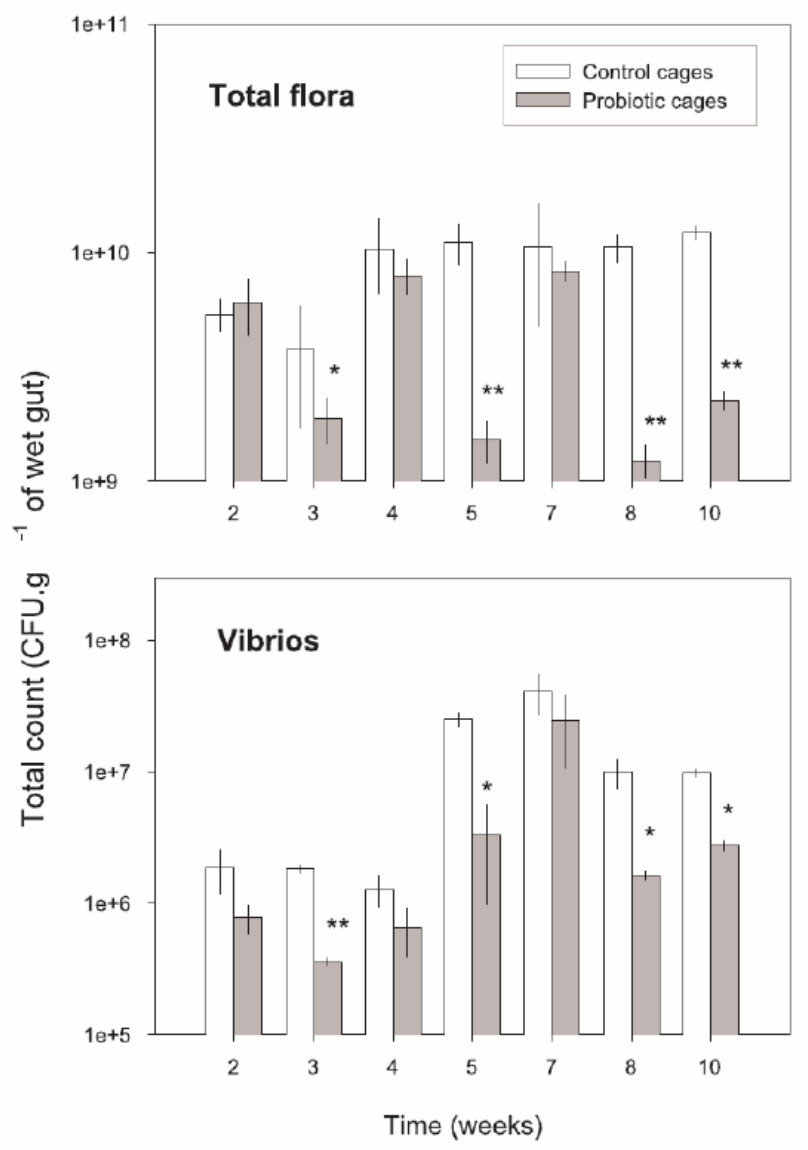

Figure 4. Bacterial counts (on Marine Agar and TCBS) in shrimp guts sampled after feeding from CCages and P-Cages over the 9 weeks of the experiment. Error bars indicate SE $(n=3)$. Superscript stars within the same sample time indicate significant differences among treatments with pairwise LSD Fisher $\left({ }^{*} \mathrm{P}<0.05 ;{ }^{* \star} \mathrm{P}<0.01\right)$. 


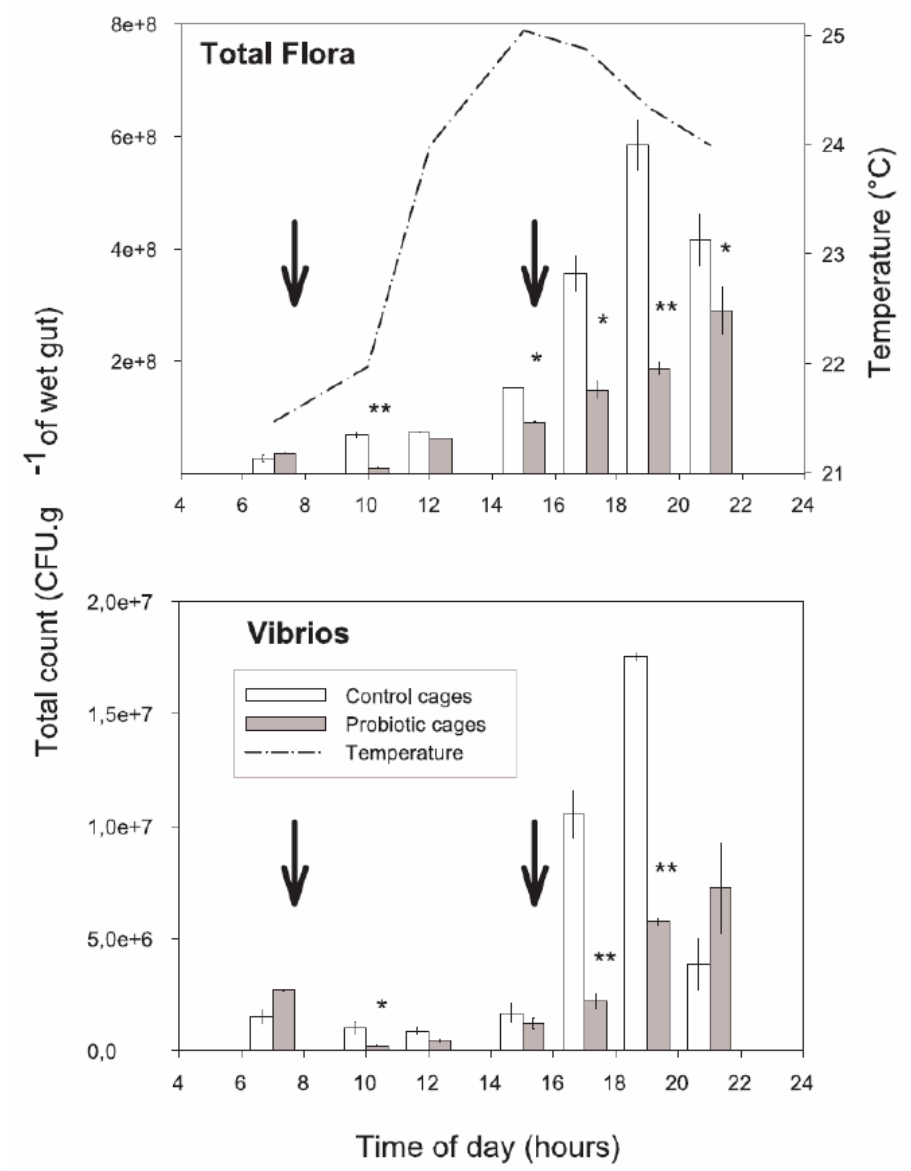

Figure 5. Bacterial counts (on Marine agar and TCBS) in shrimp guts from C-Cages and P-Cages during the 65th day of rearing in floating cages (from $7 \mathrm{am}$ to $9 \mathrm{pm}$ ). Error bars indicate SE $(n=3)$. Superscript stars within the same sample time indicate significant differences among treatments with pairwise LSD Fisher $\left({ }^{*} P<0.05 ;{ }^{*} \mathrm{P}<0.01\right)$. Dark dash line represents the water temperature over the same period. Dark arrows indicate feeding time. 

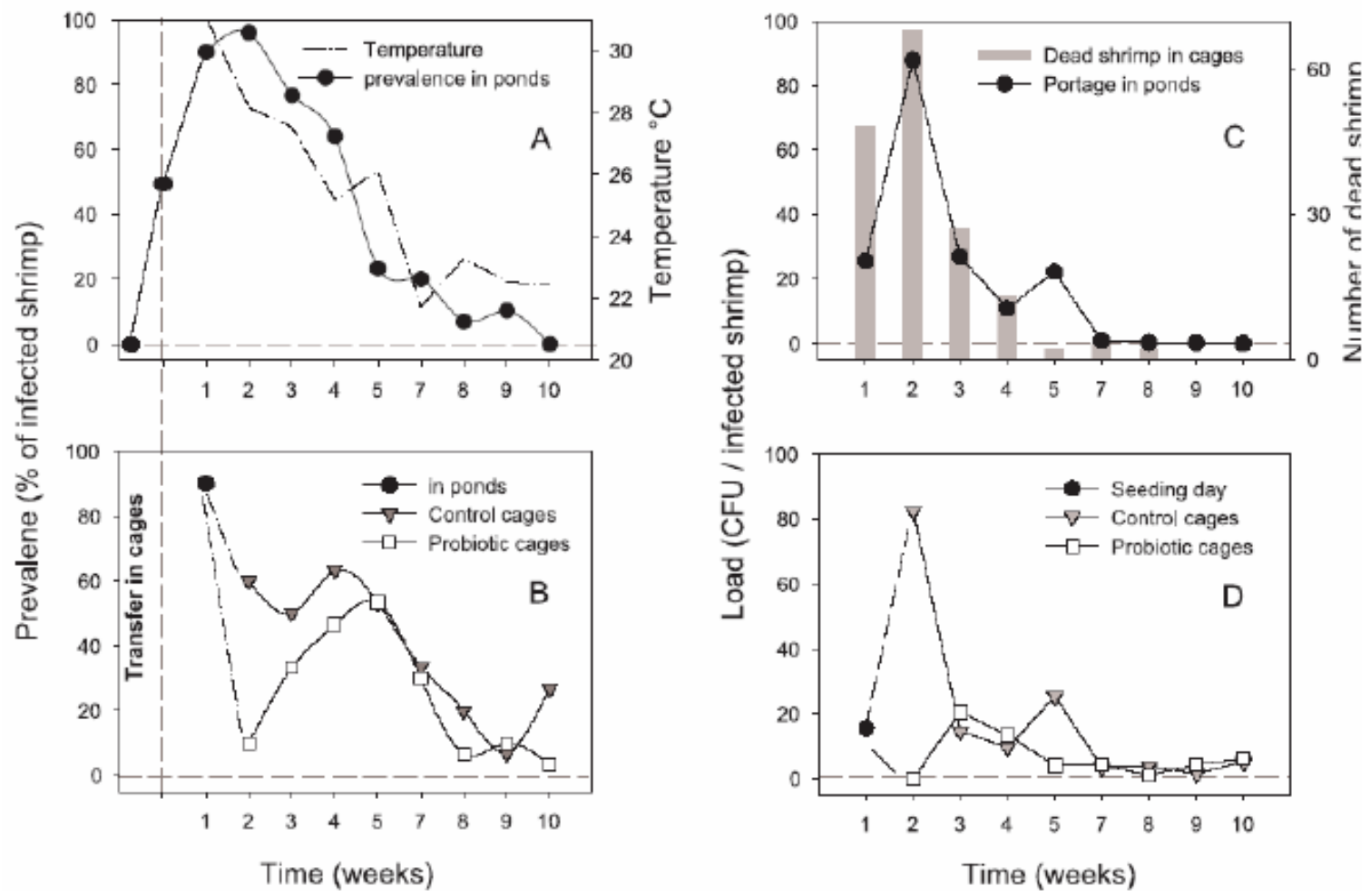

Figure 6. V. nigripulchritudo prevalence (percentage of infected animals) and load (number of $\mathrm{V}$. nigripulchritudo colonies per infected animal) of shrimps reared respectively in pond, C-Cages and PCages $(n=30)$. A. V. nigripulchritudo prevalence of shrimps sampled in pond over the period of the experiment. Dark dash line represents the water temperature over the same period. B. V. nigripulchritudo prevalence of shrimps from C-Cages and P-Cages. C. V. nigripulchritudo load of shrimps sampled in pond and weekly number of dead shrimps recorded in cages. D. V. nigripulchritudo load of shrimps from C-Cages and P-Cages. Dark arrows indicate feeding time. 